\title{
A Comparative Analysis of Real Estate Education Curricula in Botswana
}

\author{
Johnson Kampamba
}

\author{
Boipuso Nkwae
}

\section{Emmanuel Tembo}

(Department of Civil Engineering, Faculty of Engineering and Technology, University of Botswana, Botswana

Email: Johnson.kampamba@mopipi.ub.bw; nkwaeb@mopipi.ub.bw \& tembo@mopipi.ub.bw

\section{Doi:10.5901/mjss.2015.v6n5s1p105}

\section{Abstract}

The purpose of the study was to establish the level/extent of standardisation of real estate education curricula in Botswana as compared to other curricula worldwide. The data that was used in this study was collected using three main approaches; internet searches and email for programmes on real estate education worldwide, interviews with the course coordinators at the two universities in Botswana, programme brochures and real estate publications from the existing literature. The population for the study was 42 countries offering real estate education and a sampling frame was compiled based on this figure. A sample size of 30 countries was determined at $90 \%$ confidence level with a margin (standard) error of $10 \%$ using simple random sampling technique for analysis purposes. Only thirteen (13) countries responded to the survey by providing their curricula and the analysis is based on the $43.33 \%$ response rate. Only $6 \%$ of the degree courses that are being offered by the thirteen (13) universities were similar (standard) and $94 \%$ is the difference in terms of courses being offered by the learning institutions. At national level, the degree programme indicate a difference of $61 \%$ in the curricula offered by these universities while at Diploma level there is a $68 \%$ difference in courses offered at the two institutions and $73 \%$ difference at certificate level. The call for standardisation of real estate education curricula worldwide as purported by the South African Qualifications Authority and Epley is not possible as noticed from the results. This might be possible at national level where such institutions are accredited by one body and implemented as directed. The reason for the differences could be attributed to specific industry needs, different land tenure systems as well as the background knowledge of the person developing a curriculum.

Keywords: Real Estate, Education, Curricula, Similarities, Differences, Botswana

\section{Introduction}

This is a comparative study of real estate education curricula in Botswana which was meant to establish the level of standardisation as purported by the Qualifications Authority (SAQA) and National Qualifications Framework (NQF) of South Africa; and Epley (1996). This study was aimed at establishing the level and the extent of standardisation of Real Estate education curricula is Botswana. This paper has two sections, part one is the discussion of real estate education curricula at national/(local) level and part two is a global discussion of real estate education curricula aimed at establishing the similarities and differences in the curricula.

Real Estate education in Botswana has only been in existence since 2011 at University level. Since inception, no curriculum evaluation was conducted to compare subjects that are offered in real estate curricula in Botswana at a local level as well as with similar curricula internationally. Two universities run three programmes i.e. University of Botswana runs the (Bachelor of Science) BSc (Real Estate) and (Bachelor in Land Management) BLM while Ba Isago University College runs the (Bachelor of Commerce) BCom (Real Estate). All programmes that are offered at university level in Botswana are accredited by the Botswana Qualifications Authority (BQA). These three programmes are known variously in different schools for Real Estate as land management, real estate, land economy, estate management and property studies. The term land management is used here to describe these fields mentioned above, although land management is a separate programme at a few institutions/universities. The boundaries between some of these disciplines are not sharply drawn and what one institution calls real estate may largely overlap what other institution call land/estate management or land economy.

In Botswana, the field of Land Management/Real Estate is regulated by the Real Estate Professionals Act of 2007. The regulating body known as Real Estate Advisory Council (REAC) (a government body under the Department of Lands) endorses the area of practice for those who are qualified and are full members of the Real Estate Institute of 
Botswana (REIB) under the categories of Valuer, Property Manager, Auctioneer and Real Estate Agent (Republic Government of Botswana, 2007).

The problem statement of the study was developed based on existing literature/previous research done on this topic. The major issue which was raised by researchers and academics is lack of standardised Real Estate curricula in learning institutions. The main problem of this study was to evaluate "to what degree or level do the programmes offered in these two institutions in Botswana compare with other institutions' programmes in terms of the principle of standardisation as suggested by the South African Qualifications Authority (SAQA) and National Qualifications Framework (NQF)?" The paper's objective is to carry out a comparative analysis of the three programmes offered at degree level at the University of Botswana and $\mathrm{Ba}$ Isago University College in terms of curriculum structure and to establish the following: (i) the level of similarity between these curricula in Real Estate education; (ii) the difference within the curricula in Real Estate education that are being offered in these two learning institutions; and (iii) the level of standardisation as far as Real Estate education curricula in Botswana is concerned;

The overall goal is to build towards a standardisation of curriculum in Real Estate education in Botswana. While it is appreciated that standardisation of curriculum is an elusive goal since curricula are developed because of specific needs, it is considered that core curriculum can be defined in a jurisdiction such as a country or a region. Such defined curriculum would help institutions of higher learning as well as professional institutions to compare and evaluate key competencies in the area of Real Estate education. The paper, therefore, addresses the quest for acknowledging the worldwide endeavour to standardise courses in Real Estate programmes. The study is an important contribution to the evaluation of undergraduate real estate education offered in Botswana. No such studies have been conducted in part due to the new nature of the programmes in Botswana. In addition, existing level of skills and knowledge in Real Estate education should be further investigated (Epley, 1996). The study addresses the concern of this scholar by comparing and analysing the undergraduate Real Estate education curricula offered in Botswana with a view of achieving the proposed level of standardisation.

\section{Literature Review}

Education in real estate started in 1890 (Galuppo \& Worzala, 2004). In 1904, formal education began with a lecture course in New York at the West Side Nourse (1995).citing (Davies, 1958). This then implies that real estate education has been in place for over a century. A number of researchers have assessed the skills and knowledge requirements for real estate education. Epley (1996) was of the opinion that there was no agreement amongst educators on what is to be taught in real estate education because the field had not developed adequately. As such, he recommended that an indepth analysis of the different course contents in the programmes to gain an understanding of their variations and similarities was important. In a global review of real estate education, it was concluded that a universal definition in this respect was difficult to achieve due to lack of clear boundaries in the discipline (Black \& Rabianski, 2003). For instance, Carn \& Rabianski (1986) noted that classifying Real Estate Principles (core) as an elective course in many real estate programmes is a manifestation of lack of understanding amongst academics.

The purpose of this analysis of Real Estate curricula is (i) to provide support for educators who are developing their curricula; (ii) to extend the real estate literature; and (iii) to provide factors to be included when developing or reviewing real estate programmes (Finch \& Weeks, 2003). They further realised that there was no real estate programme that was being offered universally in universities. Apart from Real Estate Principles, five other course subjects that should be part of any real estate curriculum were Property Investment Analysis, Real Estate Finance, Property Market Analysis, Property Appraisal, Policy and Law (Carn \& Rabianski, 1986). Despite Real Estate Principles being regarded as a core course, it appears as an elective in some curricula (ibid). As such, an ideal real estate programme should depict the interdisciplinary and multidisciplinary nature of the field and meeting the needs/concerns of the different stakeholders of the industry (Black, Carn, Diaz, \& Rabianski, 1996). They further emphasised the importance of a programme that is capable of producing effective real estate graduates who are equipped with appropriate concepts, techniques and skills necessary for problem solving in todays' world and in the future.

There are two basic paradigms for curriculum review. The first approach focuses on the knowledge and skills that must be acquired by the students in the programme (Butler, Gunterman \& Wolverton, 1998). In order to address this challenge, active participation of these real estate industry experts in defining the learning outcomes can help to meet this requirement (Butler et al, 1998). In support of this, Cloete (2009) argued that the curriculum for real estate should be able to address the concerns/challenge of the industry and those of the regulating body. SAQA and NQF for South Africa have advocated for the standardisation of the curricula in real estate education in South Africa.

The second approach involves the acquisition of knowledge and skills through the use of a standard text book 
(Epley, 1996). However, this model fails to address really issues in the industry. (Butler, Gunterman \& Wolverton, 1998). Changing from passive learning to active learning combined with real world experience would improve the learning system (Butler, Gunterman \& Wolverton, 1998).

In Kenya, the important role of experts in the acquisition, development, valuation, management, and disposal of property was recognised at an early stage (Olima, 2006). As a result, the country invested in education, training and regulation of experts such as Land Surveyors, Valuers, Estate/Property Managers, Lawyers, Architects, Quantity Surveyors, and Planners among others (ibid). Real estate education in Kenya was first offered by the Royal Technical College of East Africa in 1956 to prepare candidates for the examination of the Royal Institution of Chartered Surveyors (RICS).

Furthermore, the curriculum for Bachelor of Arts in Land Economics is as old as the University of Nairobi (Olima, 2009). It covers broad areas including economics, construction, law, planning, appraisal, investment, management and market analysis.

\section{Research Method and Selected Real Estate Curricula}

The data used in this study was collected using three main approaches; Internet searches and email for programmes on real estate worldwide, interviews with Course Coordinators at the two universities in Botswana, programme brochures and real estate publications from the existing literature. The population for the study consisted of universities offering real estate education worldwide in the following regions: (i) Europe (20 countries), (ii) North America (two countries), (iii) Asia (eight countries), (iv) Latin America (two countries), (v) Pacific Rim (two countries), (vi) Africa (nine countries). A sampling frame comprising 43 universities offering real estate education in the world was developed. Thirty (30) (sample size $=n$ ) institutions were picked using simple random sampling at $90 \%$ confidence level with $10 \%$ margin of error for comparison purposes and analysis. Out of the thirty (30) countries that were identified, only thirteen (13) countries responded to the survey and the analysis is based on $43.33 \%$ response rate. The countries that are part of this survey are Botswana (BW), South Africa (ZA), Nigeria (NG), Tanzania (TZ), Malawi (MW), Kenya (KE), Ghana (GH), Zambia (ZM), Zimbabwe (ZW), China (CN), Baltic States (BS), Japan (JP) and South Korea (KO). Individual courses within respective real estate curricula were identified in the survey for comparison and further analysis. A global list comprising 78 degree courses was compiled and used for comparison and analysis purposes. The differences and similarities were evaluated using the global list of courses being offered in the thirteen countries.

The first step was to compare and analyse programmes that are offered by the two universities in Botswana and listed in table 1 below. Real estate curricula were compared looking at the level of qualification being offered by the institution. In this case a comparison of the courses was made for certificate, diploma and degree programmes. The reason for this evaluation was to establish how far Botswana is in terms of standardisation of real estate education curricula because graduates of these programmes are mobile and should be able to work anywhere in the world.

Table 1: Real Estate programmes offered in Botswana

\begin{tabular}{|l|c|l|l|}
\hline University \& Department & Duration & Name of Programme & Delivery \\
\hline University of Botswana (Architecture \& Planning) & 4 years & BSc Real Estate & Eight Semesters \\
\hline University of Botswana (Civil Engineering) & 4 Years & Bachelor Land Management & Eight Semesters \\
\hline Ba Isago College University (Real Estate) & 4 years & Bachelor of Commerce in Real Estate & Eight Semesters \\
\hline University of Botswana (Civil Engineering) & 2 Years & Diploma in Land Management & Four Semesters \\
\hline Ba Isago College University (Real Estate) & 2 years & Diploma in Real Estate & Four Semesters \\
\hline University of Botswana (Civil Engineering) & 1 Year & Certificate in Land Administration & Two Semesters \\
\hline Ba Isago College University (Real Estate) & 1 year & Certificate in Real Estate & Two Semesters \\
\hline
\end{tabular}

Source: University of Botswana Calendar, Ba Isago University College B.Com Real Estate Brochure (2014) and Filed survey.

\section{Results and Analysis - Comparison of Real Estate Education Curricula in Botswana}

The discussion of results in this section covers the comparison of real estate education curricula at local level in Botswana. The differences and similarities of certificate, diploma and degree in real estate education curricula are discussed under this section. The analysis of the real estate certificate, diploma and degree curricula offered in Botswana 
exhibited some topical differences and similarities. The extent of the difference in terms of topics covered is tabulated below. Tables 2, $3 \& 4$ present different courses covered from various certificate, diploma and degree programmes.

\subsection{Differences in real estate education curricula at the local level in Botswana}

Table 2 below presents the certificate curricula for real estate offered at the two institutions and is a feeder into the diploma programme. A list of 15 courses was identified and offered in two semesters.

Table 2: Comparison of certificate real estate curricula

\begin{tabular}{|c|l|c|c|}
\hline No & Core subjects offered & UB - CLA & BAISAGO - CRE \\
\hline 1 & Communication and Academic Literacy/Communication Skills & $\sqrt{ }$ & $\sqrt{ }$ \\
\hline 2 & Computer Skills/ Computer Skills Fundamentals & $\sqrt{ }$ & $\sqrt{ }$ \\
\hline 3 & Customer Service & $\mathrm{X}$ & $\sqrt{ }$ \\
\hline 4 & Introduction to Building Technology & $\mathrm{X}$ & $\sqrt{ }$ \\
\hline 5 & Introduction to Land Administration & $\sqrt{ }$ & $\mathrm{X}$ \\
\hline 6 & Introduction to Property Economics and Finance & $\mathrm{X}$ & $\sqrt{ }$ \\
\hline 7 & Introduction to Property Law/Land Policies and Law & $\sqrt{ }$ & $\sqrt{ }$ \\
\hline 8 & Introduction to Property Valuation/Introduction to Valuation & $\sqrt{ }$ & $\sqrt{ }$ \\
\hline 9 & Introduction to Public Administration & $\sqrt{ }$ & $\mathrm{X}$ \\
\hline 10 & Land Records and Information Management & $\sqrt{ }$ & $\mathrm{X}$ \\
\hline 11 & Land Surveying and Administration & $\sqrt{ }$ & $\mathrm{X}$ \\
\hline 12 & Land Use Planning & $\sqrt{ }$ & $\mathrm{X}$ \\
\hline 13 & Project & $\sqrt{ }$ & $\mathrm{X}$ \\
\hline 14 & Planning and Environment Studies & $\sqrt{ }$ & $\mathrm{X}$ \\
\hline 15 & Property Marketing & $\mathrm{X}$ & $\sqrt{ }$ \\
\hline & NB: Key VV Course offered & $\mathrm{X}=$ Course not offered & \\
\cline { 2 - 4 }
\end{tabular}

University of Botswana Undergraduate Academic Calendar 2013/2014; Ba Isago University College Certificate in Real Estate Brochure 2013/2014.

Out of these courses, 11 (73\%) was the difference in course curriculum being offered by the two universities in Botswana as illustrated in figure 1 below. The two programmes are different; therefore, standardisation of courses at the local level is not possible.

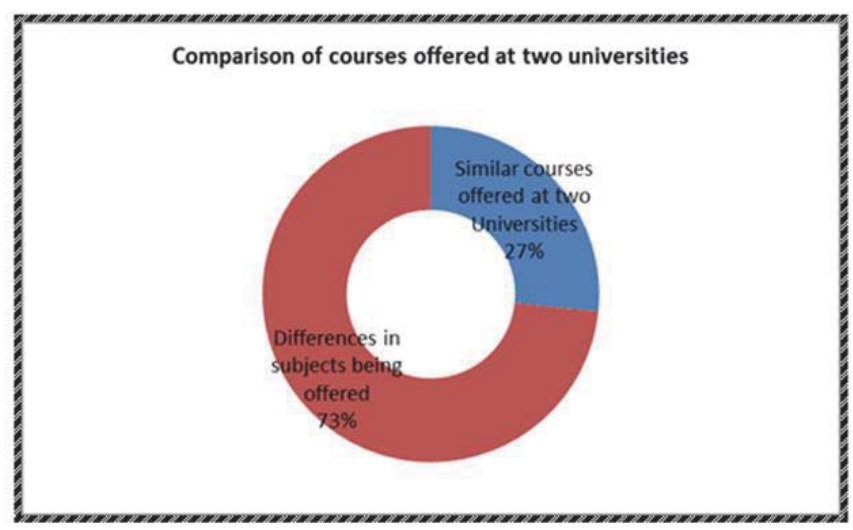

Figure 1: Comparison of certificate courses offered at two universities

$4(27 \%)$ of the courses on the list were not being offered by University of Botswana and 7 (47\%) were not offered by Ba Isago University College as shown in figure 2. 


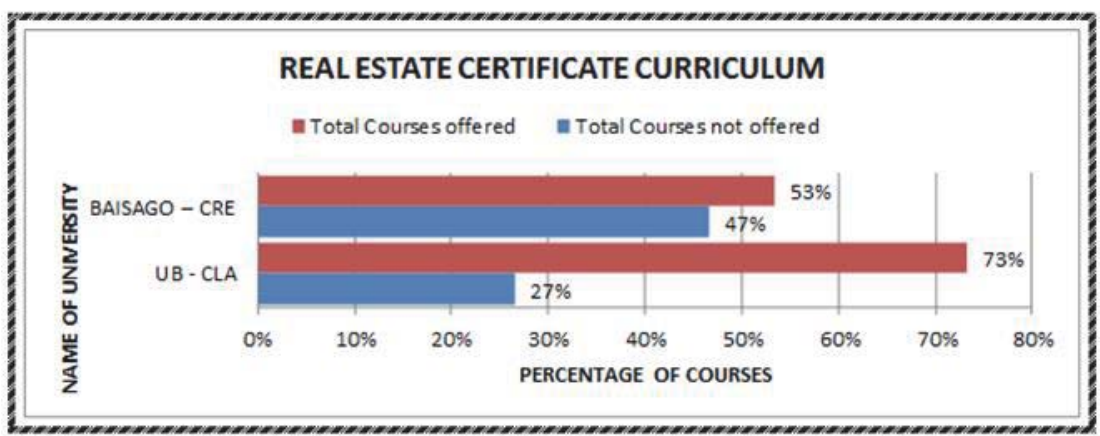

Figure 2: Certificate in Real Estate Curriculum

Under table 3 below, 25 subjects were identified as courses offered by the two universities under the Diploma - Real Estate and Land Management curricula and is also a feeder into the degree programmes of the two universities.

Table 3: Comparison of diploma in real estate curricula at the two universities in Botswana

\begin{tabular}{|c|l|c|c|}
\hline No & Core subjects offered & UB - DLA & BAISAGO - DRE \\
\hline 1 & Alternative Dispute Resolution in Land Administration & $\sqrt{ }$ & $\mathrm{X}$ \\
\hline 2 & Basic GIS & $\sqrt{ }$ & $\mathrm{X}$ \\
\hline 3 & Basics Micro and Macroeconomics /Principles of Economics & $\sqrt{ }$ & $\sqrt{ }$ \\
\hline 4 & Building Construction and Services/Building Materials I \& II & $\sqrt{ }$ & $\sqrt{ }$ \\
\hline 5 & Building Maintenance & $\mathrm{X}$ & $\sqrt{ }$ \\
\hline 6 & Business Planning and Entrepreneurship & $\mathrm{X}$ & $\sqrt{ }$ \\
\hline 7 & Communication and Academic Literacy I \& II & $\sqrt{ }$ & $\mathrm{X}$ \\
\hline 8 & Computer Skills Fundamentals I \& II & $\sqrt{ }$ & $\mathrm{X}$ \\
\hline 9 & Elementary Statistics/Quantitative Methods/Mathematics I & $\sqrt{ }$ & $\sqrt{ }$ \\
\hline 10 & Geomatics/Plane Surveying & $\sqrt{ }$ & $\sqrt{ }$ \\
\hline 11 & Industrial Attachment/Industrial Training & $\sqrt{ }$ & $\sqrt{ }$ \\
\hline 12 & Introduction to Information Management & $\sqrt{ }$ & $\mathrm{X}$ \\
\hline 13 & Introduction to Planning and Built Environment/Town and Country Planning & $\sqrt{ }$ & $\sqrt{ }$ \\
\hline 15 & Land Economics & $\sqrt{ }$ & $\mathrm{X}$ \\
\hline 16 & Introduction to Land Administration & $\sqrt{ }$ & $\mathrm{X}$ \\
\hline 17 & Law and Society in Botswana/Law for Geomatics/Property Law & $\sqrt{ }$ & $\sqrt{ }$ \\
\hline 18 & Principles of Financial Accounting & $\mathrm{X}$ & $\sqrt{ }$ \\
\hline 19 & Principles of Valuation/Methods of Valuation/Property Valuation & $\sqrt{ }$ & $\sqrt{ }$ \\
\hline 20 & Project Management & $\mathrm{X}$ & $\sqrt{ }$ \\
\hline 21 & Property Auctioneering & $\mathrm{X}$ & $\sqrt{ }$ \\
\hline 22 & Property Management & $\mathrm{X}$ & $\sqrt{ }$ \\
\hline 23 & Property Marketing & $\mathrm{X}$ & $\sqrt{ }$ \\
\hline 24 & Public Administration in Botswana & $\sqrt{ }$ & $\mathrm{X}$ \\
\hline 25 & Real Estate Investment and Finance & $\mathrm{X}$ & $\sqrt{ }$ \\
\hline
\end{tabular}

University of Botswana Undergraduate Academic Calendar 2013/2014; Ba Isago University College Diploma in Real Estate Brochure 2013/2014 and field survey.

$18(68 \%)$ of these courses are different in the diploma curricula between the two institutions as shown in figure 3 . 


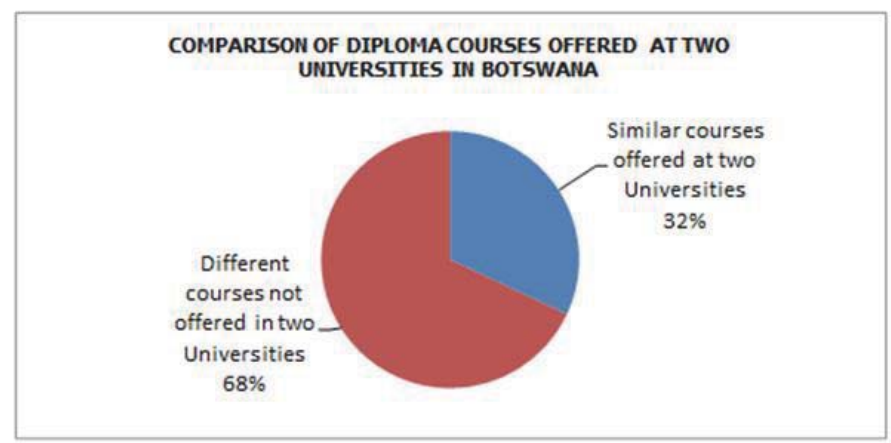

Figure 3: Comparison of Diploma courses in two Universities in Botswana

8 (32\%) of the courses on the list were not being offered by University of Botswana and 9 (35\%) were not offered by Ba Isago University College as highlighted in figure 4 below. Graduates from these universities are admitted into degree programmes by any of these two institutions, it is to their best advantage if the curricula do not differ in any aspect because this impact on the performance of students.

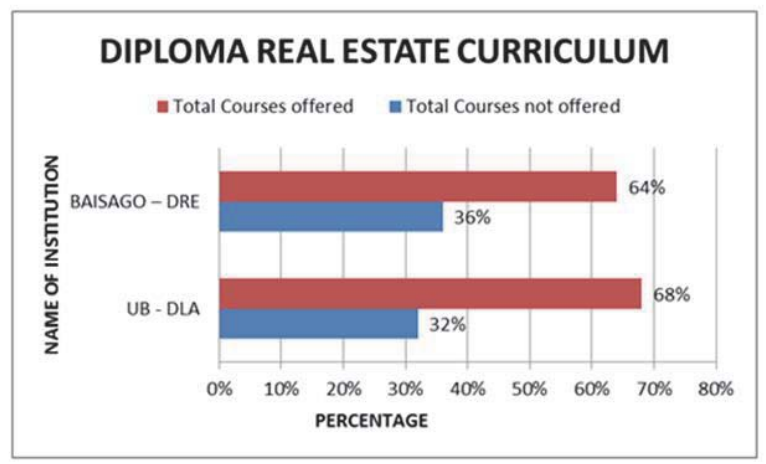

Figure 4: Diploma Real Estate Curriculum in two Universities in Botswana

The results revealed that the programmes are different consisting of a variety of courses despite some similarities in courses offered. The total number of subjects being offered in degree curricula in Botswana is 46 . The table below shows the subjects that are being offered by the universities under study as well as the differences in those subjects that are not being offered. It was revealed that 28 out of 46 subjects are not offered by all the three departments under study in Botswana, representing $61 \%$ disagreement on course offerings as illustrated in table 4 below.

Table 4: Comparison of topics offered in Real Estate Degree programmes/curricula in Botswana by the two universities

\begin{tabular}{|l|c|c|c|}
\hline Core subjects offered & UB - BSc. RE & UB - BLM & BAISAGO - BCom RE \\
\hline Basic Microeconomics and Macroeconomics & $\sqrt{ }$ & $\sqrt{ }$ & $\sqrt{ }$ \\
\hline Mathematics for Business and Social Sciences & $\sqrt{ }$ & $\sqrt{ }$ & X \\
\hline Introduction to Law, and Land Law for Geomatics & $\sqrt{ }$ & $\sqrt{ }$ & $\sqrt{ }$ \\
\hline Introduction to Real Estate & $\sqrt{ }$ & $\sqrt{ }$ & $x$ \\
\hline Communication and Academic Literacy & $\sqrt{ }$ & $\sqrt{ }$ & $\sqrt{ }$ \\
\hline Computer Skills Fundamentals & $\sqrt{ }$ & $\sqrt{ }$ & $\sqrt{ }$ \\
\hline Property Valuation & $\sqrt{ }$ & $\sqrt{ }$ & $\sqrt{ }$ \\
\hline Property Auctioneering & $\mathrm{x}$ & $\mathrm{x}$ & $\sqrt{ }$ \\
\hline
\end{tabular}




\begin{tabular}{|c|c|c|c|}
\hline Building Materials I \& II & $\sqrt{ }$ & $\sqrt{ }$ & $x$ \\
\hline Building Construction and Services & $\mathrm{x}$ & $\mathrm{x}$ & $\sqrt{ }$ \\
\hline Land Economics I \& II & $\sqrt{ }$ & $\sqrt{ }$ & $\sqrt{ }$ \\
\hline Introduction to Planning and Built Environment & $\sqrt{ }$ & $\sqrt{ }$ & $\sqrt{ }$ \\
\hline Business Planning and Entrepreneurship & $\mathrm{x}$ & $\sqrt{ }$ & $\sqrt{ }$ \\
\hline Principles of Management \& Organisation Design & $\mathrm{x}$ & $\sqrt{ }$ & $x$ \\
\hline Property Maintenance & $\mathrm{x}$ & $\mathrm{x}$ & $\sqrt{ }$ \\
\hline Elementary Statistics & $\sqrt{ }$ & $\sqrt{ }$ & $\mathrm{x}$ \\
\hline Quantitative Methods & $\mathrm{x}$ & $\mathrm{x}$ & $\sqrt{ }$ \\
\hline Introduction to Land Administration & $\sqrt{ }$ & $\sqrt{ }$ & $\sqrt{ }$ \\
\hline Principles of GIS & $\sqrt{ }$ & $\sqrt{ }$ & $x$ \\
\hline Facilities Management & $\sqrt{ }$ & $\sqrt{ }$ & $\sqrt{ }$ \\
\hline Introduction to Accounting & $\sqrt{ }$ & $\sqrt{ }$ & $\mathrm{x}$ \\
\hline Cost Accounting & $x$ & $\mathrm{x}$ & $\sqrt{ }$ \\
\hline Principles of Finance and Accounting & $\mathrm{x}$ & $\mathrm{x}$ & $\sqrt{ }$ \\
\hline Industrial Training I \& II & $\sqrt{ }$ & $\sqrt{ }$ & $\sqrt{ }$ \\
\hline Housing Economics and Policies & $\sqrt{ }$ & $\sqrt{ }$ & $\sqrt{ }$ \\
\hline Real Estate Marketing and Agency & $\sqrt{1}$ & $\sqrt{1}$ & $\sqrt{1}$ \\
\hline Property Development and Finance & $\sqrt{ }$ & $\sqrt{ }$ & $\sqrt{ }$ \\
\hline Geomatics & $\sqrt{ }$ & $\sqrt{ }$ & $\sqrt{ }$ \\
\hline Property Management & $\sqrt{ }$ & $\sqrt{ }$ & $\sqrt{ }$ \\
\hline Property Investment and Appraisal & $\sqrt{ }$ & $\sqrt{ }$ & $\sqrt{ }$ \\
\hline Property Conveyance and Disposition & $\sqrt{ }$ & $\sqrt{ }$ & $\mathrm{x}$ \\
\hline Development Economics & $\mathrm{x}$ & $x$ & $\sqrt{ }$ \\
\hline Project Planning and Implementation & $\sqrt{ }$ & $\sqrt{ }$ & $\sqrt{ }$ \\
\hline Public Administration in Botswana & $\mathrm{x}$ & $\sqrt{ }$ & $\mathrm{x}$ \\
\hline Alternative Dispute Resolution in Land Admin & $\mathrm{x}$ & $\sqrt{ }$ & $x$ \\
\hline Remote Sensing for Land Management & $\mathrm{x}$ & $\sqrt{ }$ & $\mathrm{x}$ \\
\hline Computer Applications for Real Estate & $\sqrt{ }$ & $\sqrt{ }$ & $x$ \\
\hline Elective Course & $\mathrm{x}$ & $\sqrt{ }$ & $x$ \\
\hline Professional Ethics & $\sqrt{ }$ & $\sqrt{ }$ & $\mathrm{x}$ \\
\hline Tribal Land Management & $\mathrm{x}$ & $\sqrt{ }$ & $\mathrm{x}$ \\
\hline Research Project & $\sqrt{ }$ & $\sqrt{ }$ & $\sqrt{ }$ \\
\hline Research Methodology & $\sqrt{ }$ & $\mathrm{x}$ & $\sqrt{ }$ \\
\hline Business Strategy & $\mathrm{x}$ & $\mathrm{x}$ & $\sqrt{ }$ \\
\hline Global Business Environment & $\mathrm{x}$ & $\mathrm{x}$ & $\sqrt{ }$ \\
\hline Organisational Psychology & $\mathrm{x}$ & $x$ & $\sqrt{ }$ \\
\hline International Property Markets & $x$ & $x$ & $\sqrt{ }$ \\
\hline
\end{tabular}

Sources: University of Botswana Undergraduate Academic Calendar 2013/2014; Ba Isago University College Bachelor of Commerce Real Estate Brochure 2013/2014.

Figure 5 below indicates that $16(35 \%)$ out of 46 courses are not being offered by the BSc. Real Estate programme at UB; $14(30 \%)$ out of 46 courses are not offered by Bachelor of Land Management programme at UB and 15 (33\%) courses are not offered by Ba Isago BCom Real Estate programme. Surprisingly, some courses that are expected in Real Estate curricula were not being offered by the three departments in the two universities offering real estate education in Botswana such as Real Estate Principles and Corporate Real Estate even though they are covered as topics in other courses. The differences in courses offered could be attributed to different property industries' needs and relevance as well as the perceptions of the curriculum developers. It is clear that the variation in course content can have an effect on the quality of products in Botswana that are meant to serve the same market/industry. 


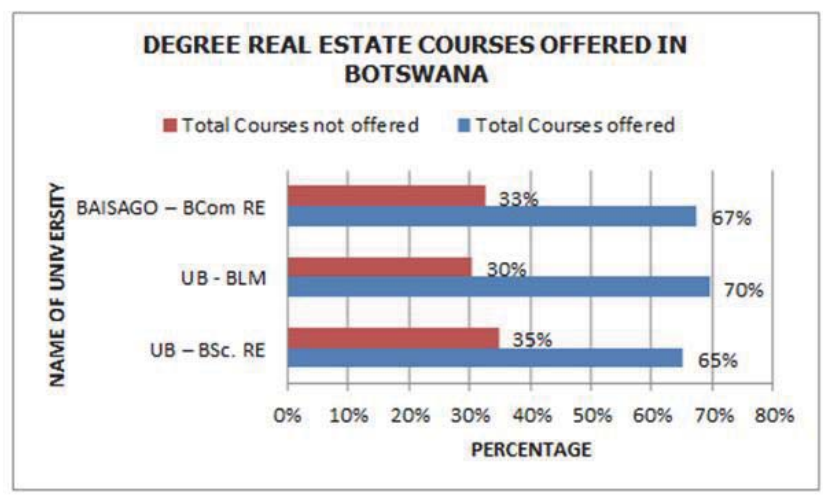

Figure 5: Degree real estate courses offered in Botswana by the three Departments

Out of the 35 course subjects offered by the University of Botswana, 17\% (6) of these were being offered by Land Management programme in the Department of Civil Engineering and 6\% (2) by Real Estate programme in the Department of Architecture and Planning. In conclusion, there is a $23 \%$ difference in the course curricula of the two programmes being offered by the University of Botswana. Apart from the general common courses, land management programme is offering five additional courses which are Dispute Resolution for Land Administration, Elementary Statistics, Public Administration, Remote Sensing for Land Management and Tribal Land Management. The Real Estate programme offers two courses which are Business Planning and Entrepreneurship and Research Methodology.

\subsection{Similarities in real estate education curricula at local level in Botswana}

The certificate curricula between the two universities in Botswana have also exhibited some similarity as shown in figure 1. $27 \%$ of the courses offered in these institutions are similar.

The diploma curricula also show that $32 \%$ of the courses in figure 3 are similar in the two real estate education curricula offered by the two universities in Botswana.

The results of the analysis of the two universities' curricula in figure 6 have some similar topics expected in a degree real estate curriculum. 39\% of the subjects are similar in the three curricula that were analysed and $59 \%$ of the subjects in the two departments of the University of Botswana were similar to some extent. In table 4, it is shown that most of the subjects are offered across the three departments in two universities. It can then be concluded that despite the courses being offered in three departments of the two universities there are some (39\%) agreement on the standard courses being offered in real estate education in Botswana to some extent.

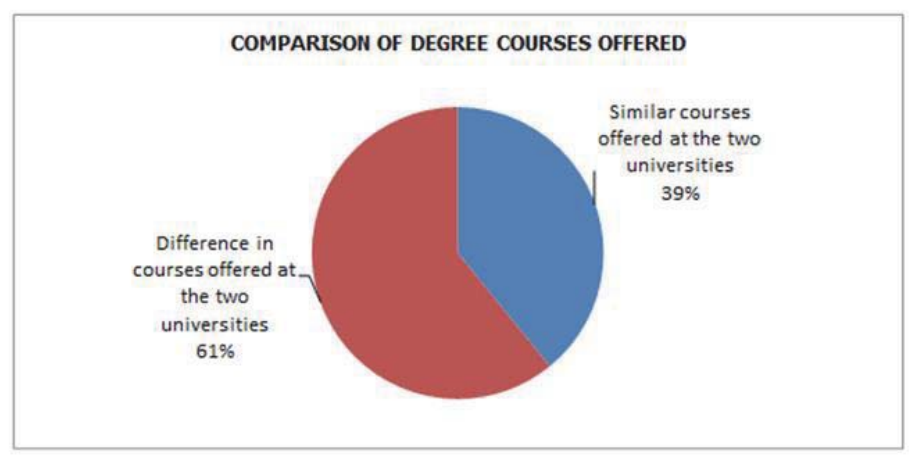

Figure 6: Comparison of real estate courses offered in Botswana 
From the analysis of the courses offered by the two departments in the University of Botswana, it was clear that $77 \%$ (27) of the course subjects were similar in the two curricula of land management and real estate.

\subsection{Comparison of real estate curricula offered in Botswana and other countries.}

Table 5: Comparison of real estate curriculum offered in Botswana and those offered in other countries.

\begin{tabular}{|c|c|c|c|c|c|c|c|c|c|c|c|c|c|c|}
\hline \multirow{2}{*}{ No } & \multirow{2}{*}{ Core subjects offered } & \multicolumn{2}{|c|}{\begin{tabular}{|l|l|}
$B W$ & $Z A$ \\
\end{tabular}} & \multicolumn{2}{|c|}{ KE } & & \multirow{2}{*}{\begin{tabular}{|c|} 
MW \\
6
\end{tabular}} & \multicolumn{2}{|c|}{ NG } & 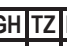 & $\overline{B S}$ C & \multicolumn{3}{|c|}{\begin{tabular}{l|l|l|l|l} 
CN & $\mathrm{JP}$ & $\mathrm{KO}$ \\
\end{tabular}} \\
\hline & & 1 & 2 & 3 & & & & 7 & 8 & 9 & 10 & 11 & 12 & \\
\hline 1 & Accounting Principles/Introduction to Accounting & $\sqrt{ }$ & $\sqrt{ }$ & $\mathrm{x}$ & $\mathrm{x}$ & $\mathrm{x}$ & $\mathrm{x}$ & $\sqrt{ }$ & $\sqrt{ }$ & $\mathrm{x}$ & $\mathrm{x}$ & $\mathrm{x}$ & $\sqrt{1}$ & $\mathrm{x}$ \\
\hline 2 & Administrative and Local Government Law & $\mathrm{x}$ & $\mathrm{x}$ & $\sqrt{1}$ & $\mathrm{x}$ & $\mathrm{x}$ & $\mathrm{x}$ & $\mathrm{x}$ & $\sqrt{ }$ & $\mathrm{x}$ & $\mathrm{x}$ & $\mathrm{x}$ & $\sqrt{ }$ & $\bar{x}$ \\
\hline 3 & Agricultural Economics and Management & $\mathrm{x}$ & $\mathrm{x}$ & $\sqrt{ }$ & $\bar{x}$ & $\mathrm{x}$ & $\mathrm{x}$ & $\sqrt{ }$ & $\sqrt{ }$ & $\mathrm{x}$ & $\mathrm{x}$ & $\bar{x}$ & $\mathrm{x}$ & $\bar{x}$ \\
\hline 4 & Alternative Dispute Resolution in Land Admin/Property Dispute Resolution & $\sqrt{ }$ & $\mathrm{x}$ & $\sqrt{1}$ & $\mathrm{x}$ & $\mathrm{x}$ & $\mathrm{x}$ & $\sqrt{ }$ & $\mathrm{x}$ & $\mathrm{x}$ & $\mathrm{x}$ & $\mathrm{x}$ & $\mathrm{x}$ & $\bar{x}$ \\
\hline 5 & Applied Corporate Finance/Business Finance & $\mathrm{x}$ & $\sqrt{ }$ & $\mathrm{x}$ & $\sqrt{ }$ & $\mathrm{x}$ & $\mathrm{x}$ & $\mathrm{x}$ & $\mathrm{x}$ & $\mathrm{x}$ & $\mathrm{x}$ & $\mathrm{x}$ & $\mathrm{x}$ & $\bar{x}$ \\
\hline 6 & Architectural Drawing and Design/Plan for Property Developers/Studio Projects & $\mathrm{x}$ & $\sqrt{1}$ & $\sqrt{ }$ & $\sqrt{ }$ & $\mathrm{x}$ & $\sqrt{ }$ & $\sqrt{ }$ & $\mathrm{x}$ & $\sqrt{1}$ & $\mathrm{x}$ & $\mathrm{x}$ & $\mathrm{x}$ & $\mathrm{x}$ \\
\hline 7 & Basic Microeconomics and Macroeconomics & $\sqrt{1}$ & $\sqrt{1}$ & $\sqrt{ }$ & $\sqrt{ }$ & $\sqrt{ }$ & $\sqrt{ }$ & $\sqrt{ }$ & $\sqrt{ }$ & $\sqrt{1}$ & $\sqrt{ }$ & $\sqrt{ }$ & $\sqrt{ }$ & $\sqrt{ }$ \\
\hline 8 & $\begin{array}{l}\text { Building Construction and Services/Construction Technology I \& II/Building } \\
\text { Technology I \& II }\end{array}$ & $\sqrt{ }$ & $\sqrt{ }$ & $\sqrt{ }$ & $\sqrt{ }$ & $\sqrt{ }$ & $\sqrt{ }$ & $\sqrt{ }$ & $\sqrt{ }$ & $\sqrt{ }$ & $\sqrt{ }$ & $\sqrt{ }$ & $\sqrt{ }$ & $\sqrt{ }$ \\
\hline 9 & Building Materials and Finishes/Building Materials I \& II & $\sqrt{ }$ & $\mathrm{x}$ & $\sqrt{ }$ & $\mathrm{x}$ & $\mathrm{x}$ & $\mathrm{x}$ & $\mathrm{x}$ & $\mathrm{x}$ & $\mathrm{x}$ & $\mathrm{x}$ & $\mathrm{x}$ & $\mathrm{x}$ & $\mathrm{x}$ \\
\hline 10 & Building Science I & $\mathrm{x}$ & $\sqrt{ }$ & $\mathrm{x}$ & $\mathrm{x}$ & $\mathrm{x}$ & $\mathrm{x}$ & $\mathrm{x}$ & $\mathrm{x}$ & $\mathrm{x}$ & $\sqrt{ }$ & $\mathrm{x}$ & $\mathrm{x}$ & $\mathrm{x}$ \\
\hline 11 & $\begin{array}{l}\text { Business Planning and Entrepreneurship/Entrepreneurship and } \\
\text { Innovation/Entrepreneurial Studies }\end{array}$ & $\sqrt{ }$ & $\sqrt{ }$ & $\sqrt{ }$ & $\mathrm{x}$ & $\mathrm{x}$ & $\mathrm{x}$ & $\mathrm{x}$ & $\sqrt{ }$ & $\mathrm{x}$ & $\mathrm{x}$ & $\sqrt{ }$ & $\mathrm{x}$ & $\mathrm{x}$ \\
\hline 12 & Business Strategy & $\sqrt{ }$ & $\mathrm{x}$ & $\mathrm{x}$ & $\mathrm{x}$ & $\mathrm{x}$ & $\mathrm{x}$ & $\mathrm{x}$ & $\mathrm{x}$ & $x$ & $\mathrm{x}$ & $\mathrm{x}$ & $\mathrm{x}$ & $\mathrm{x}$ \\
\hline 13 & Commercial Law & $\mathrm{x}$ & $\sqrt{ }$ & $\mathrm{x}$ & $x$ & $\sqrt{ }$ & $x$ & $x$ & $x$ & $x$ & $\mathrm{x}$ & $\mathrm{x}$ & $\mathrm{x}$ & $\sqrt{ }$ \\
\hline 14 & Commercial Real Estate Investments & $x$ & $\sqrt{ }$ & $\mathrm{x}$ & $\mathrm{x}$ & $\mathrm{x}$ & $x$ & $x$ & $\mathrm{x}$ & $x$ & $\mathrm{x}$ & $\mathrm{x}$ & $\mathrm{x}$ & $x$ \\
\hline 15 & Communication and Academic Literacy/Communication Skills & $\sqrt{ }$ & $\sqrt{ }$ & $\sqrt{ }$ & $\mathrm{x}$ & $\mathrm{x}$ & $\sqrt{ }$ & $\sqrt{ }$ & $\mathrm{x}$ & $\sqrt{1}$ & $\mathrm{x}$ & $\mathrm{x}$ & $\mathrm{x}$ & $\bar{x}$ \\
\hline 16 & Computer Applications for Real Estate & $\sqrt{ }$ & $\mathrm{x}$ & $\mathrm{x}$ & $\sqrt{1}$ & $\mathrm{x}$ & $\mathrm{x}$ & $\mathrm{x}$ & $\mathrm{x}$ & $\sqrt{ }$ & $\mathrm{x}$ & $\sqrt{ }$ & $\mathrm{x}$ & $\bar{x}$ \\
\hline 17 & Computer Skills Fundamentals/Introduction to Computing & $\sqrt{ }$ & $x$ & $\sqrt{1}$ & $\mathrm{x}$ & $\mathrm{x}$ & $\sqrt{1}$ & $\sqrt{ }$ & $\sqrt{ }$ & $x$ & $\mathrm{x}$ & $\mathrm{x}$ & $\mathrm{x}$ & $\bar{x}$ \\
\hline 18 & Contracts and Procurement in Real Estate Services & $\mathrm{x}$ & $\mathrm{x}$ & $\sqrt{1}$ & $\mathrm{x}$ & $\sqrt{ }$ & $\mathrm{x}$ & $\mathrm{x}$ & $\mathrm{x}$ & $x$ & $\mathrm{x}$ & $\mathrm{x}$ & $\mathrm{x}$ & $\bar{x}$ \\
\hline 19 & Corporate Real Estate & $\mathrm{x}$ & $\sqrt{ }$ & $x$ & $\mathrm{x}$ & $\mathrm{x}$ & $\mathrm{x}$ & $\mathrm{x}$ & $\mathrm{x}$ & $\mathrm{x}$ & $\sqrt{ }$ & $\mathrm{x}$ & $\mathrm{x}$ & $\bar{x}$ \\
\hline 20 & Cost Accounting/Financial Accounting & $\sqrt{ }$ & $x$ & $x$ & $\sqrt{ }$ & $x$ & $x$ & $x$ & $x$ & $x$ & $x$ & $\mathrm{x}$ & $\mathrm{x}$ & $x$ \\
\hline 21 & Development Economics & $\sqrt{ }$ & $\mathrm{x}$ & $\mathrm{x}$ & $\sqrt{ }$ & $x$ & $\sqrt{ }$ & $x$ & $x$ & $x$ & $x$ & $x$ & $x$ & $x$ \\
\hline 22 & Elective Course & $\sqrt{ }$ & $x$ & $x$ & $x$ & $x$ & $x$ & $x$ & $x$ & $x$ & $x$ & $x$ & $x$ & $x$ \\
\hline 23 & $\begin{array}{l}\text { Elementary Statistics/Statistics for Business/Real Estate Statistics I \& II/Mathematics } \\
\text { and statistics }\end{array}$ & $\sqrt{ }$ & $\sqrt{ }$ & $\sqrt{ }$ & $\sqrt{ }$ & $\mathrm{x}$ & $\sqrt{ }$ & $\sqrt{ }$ & $\sqrt{ }$ & $\sqrt{ }$ & $\mathrm{x}$ & $x$ & $\sqrt{ }$ & $\mathrm{x}$ \\
\hline 24 & Elements of Law and Government & $\mathrm{x}$ & $\mathrm{x}$ & $\sqrt{ }$ & $\mathrm{x}$ & $\mathrm{x}$ & $\mathrm{x}$ & $\mathrm{x}$ & $\sqrt{1}$ & $\sqrt{1}$ & $\mathrm{x}$ & $\mathrm{x}$ & $\mathrm{x}$ & $\mathrm{x}$ \\
\hline 25 & Environmental Impact Assessment/Environmental Impact Assessment and Audits & $\mathrm{x}$ & $\sqrt{ }$ & $\sqrt{ }$ & $\mathrm{x}$ & $\sqrt{ }$ & $\sqrt{ }$ & $\sqrt{1}$ & $\mathrm{x}$ & $\sqrt{1}$ & $\mathrm{x}$ & $\mathrm{x}$ & $\mathrm{x}$ & $\bar{x}$ \\
\hline 26 & Environmental Science & $\mathrm{x}$ & $\mathrm{x}$ & $\sqrt{1}$ & $\mathrm{x}$ & $\mathrm{x}$ & $\mathrm{x}$ & $\sqrt{ }$ & $\mathrm{x}$ & $\mathrm{x}$ & $\mathrm{x}$ & $\mathrm{x}$ & $\mathrm{x}$ & $\bar{x}$ \\
\hline 27 & Facilities Management/Property and Facilities Management I \& II & $\sqrt{ }$ & $\sqrt{ }$ & $\sqrt{ }$ & $\mathrm{x}$ & $\mathrm{x}$ & $\sqrt{ }$ & $\mathrm{x}$ & $\mathrm{x}$ & $\mathrm{x}$ & $\sqrt{ }$ & $\sqrt{ }$ & $\sqrt{ }$ & $\mathrm{x}$ \\
\hline 28 & Geomatics/Introduction to Land Surveying/Land Surveying & $\sqrt{1}$ & $\mathrm{x}$ & $\sqrt{1}$ & $\sqrt{ }$ & $x$ & $\sqrt{ }$ & $\sqrt{ }$ & $\sqrt{ }$ & $x$ & $\mathrm{x}$ & $\mathrm{x}$ & $\mathrm{x}$ & $\bar{x}$ \\
\hline 29 & Global Business Environment & $\sqrt{ }$ & $\mathrm{x}$ & $\mathrm{x}$ & $\mathrm{x}$ & $x$ & $x$ & $x$ & $\mathrm{x}$ & $x$ & $x$ & $x$ & $\mathrm{x}$ & $\bar{x}$ \\
\hline 30 & HIVIAIDS & $\mathrm{x}$ & $\mathrm{x}$ & $\sqrt{ }$ & $\mathrm{x}$ & $\mathrm{x}$ & $\mathrm{x}$ & $\mathrm{x}$ & $\mathrm{x}$ & $\mathrm{x}$ & $\mathrm{x}$ & $\mathrm{x}$ & $\mathrm{x}$ & $x$ \\
\hline 31 & Housing Administration & $\mathrm{x}$ & $\mathrm{x}$ & $\sqrt{ }$ & $\mathrm{x}$ & $\mathrm{x}$ & $\mathrm{x}$ & $\mathrm{x}$ & $\mathrm{x}$ & $x$ & $\mathrm{x}$ & $\mathrm{x}$ & $\mathrm{x}$ & $x$ \\
\hline 32 & Housing and Property Economics/Housing Economics and Policies & $\sqrt{ }$ & $\mathrm{x}$ & $\sqrt{ }$ & $\mathrm{x}$ & $\mathrm{x}$ & $\mathrm{x}$ & $\sqrt{1}$ & $\mathrm{x}$ & $x$ & $\sqrt{1}$ & $\sqrt{ }$ & $\mathrm{x}$ & $x$ \\
\hline 33 & Industrial Training I \& II/Practical Training & $\sqrt{ }$ & $\mathrm{x}$ & $\mathrm{x}$ & $\sqrt{1}$ & $\mathrm{x}$ & $\mathrm{x}$ & $\mathrm{x}$ & $\mathrm{x}$ & $\mathrm{x}$ & $\mathrm{x}$ & $\mathrm{x}$ & $\mathrm{x}$ & $\mathrm{x}$ \\
\hline 34 & Intellectual property Law & $\mathrm{x}$ & $\mathrm{x}$ & $\mathrm{x}$ & $\sqrt{ }$ & $x$ & $\mathrm{x}$ & $\mathrm{x}$ & $\mathrm{x}$ & $x$ & $\mathrm{x}$ & $\mathrm{x}$ & $\mathrm{x}$ & $\mathrm{x}$ \\
\hline 35 & International Property Markets & $\sqrt{ }$ & $\mathrm{x}$ & $\mathrm{x}$ & $\mathrm{x}$ & $\mathrm{x}$ & $\mathrm{x}$ & $\mathrm{x}$ & $\mathrm{x}$ & $x$ & $\mathrm{x}$ & $\mathrm{x}$ & $\mathrm{x}$ & $\bar{x}$ \\
\hline 36 & Introduction to Land Administration/Land Administration and Management & $\sqrt{ }$ & $\mathrm{x}$ & $\sqrt{ }$ & $\mathrm{x}$ & $\sqrt{ }$ & $\mathrm{x}$ & $\sqrt{ }$ & $\mathrm{x}$ & $\sqrt{1}$ & $\mathrm{x}$ & $\mathrm{x}$ & $\sqrt{1}$ & $\sqrt{ }$ \\
\hline 37 & Introduction to Law, and Land Law for Geomatics/Business Law & $\sqrt{1}$ & $\mathrm{x}$ & $\sqrt{ }$ & $\mathrm{x}$ & $\sqrt{ }$ & $\sqrt{ }$ & $\mathrm{x}$ & $\sqrt{ }$ & $\sqrt{1}$ & $\mathrm{x}$ & $\mathrm{x}$ & $\sqrt{1}$ & $x$ \\
\hline 38 & $\begin{array}{l}\text { Introduction to Planning and Built Environment/Elements of Urban and Regional } \\
\text { Planning }\end{array}$ & $\sqrt{ }$ & $\mathrm{x}$ & $\sqrt{ }$ & $x$ & $\sqrt{ }$ & $\sqrt{ }$ & $\sqrt{ }$ & $\mathrm{x}$ & $\mathrm{x}$ & $\sqrt{ }$ & $\mathrm{x}$ & $\sqrt{ }$ & $\sqrt{ }$ \\
\hline 39 & Introduction to Real Estate & $\sqrt{ }$ & $x$ & $\sqrt{ }$ & $\mathrm{x}$ & $x$ & $\sqrt{ }$ & $x$ & $x$ & $x$ & $\mathrm{x}$ & $\sqrt{ }$ & $\mathrm{x}$ & $\sqrt{1}$ \\
\hline 40 & Introductory Econometrics & $x$ & $\sqrt{ }$ & $\mathrm{x}$ & $\mathrm{x}$ & $x$ & $x$ & $\sqrt{ }$ & $x$ & $\mathrm{x}$ & $x$ & $x$ & $\mathrm{x}$ & $x$ \\
\hline 41 & Land Economics I \& II/Urban Economics & $\sqrt{ }$ & $\sqrt{ }$ & $\sqrt{ }$ & $\sqrt{1}$ & $\sqrt{ }$ & $\sqrt{ }$ & $\sqrt{ }$ & $\sqrt{ }$ & $\sqrt{1}$ & $\sqrt{1}$ & $\sqrt{ }$ & $\sqrt{1}$ & $\sqrt{ }$ \\
\hline 42 & Land Information Systems & $\mathrm{x}$ & $x$ & $\sqrt{ }$ & $\mathrm{x}$ & $x$ & $x$ & $\mathrm{x}$ & $\mathrm{x}$ & $\sqrt{1}$ & $\mathrm{x}$ & $\mathrm{x}$ & $\mathrm{x}$ & $\mathrm{x}$ \\
\hline 43 & Land Policy Studies/Land Policy and development & $\mathrm{x}$ & $\mathrm{x}$ & $\sqrt{ }$ & $\sqrt{1}$ & $x$ & $x$ & $\sqrt{1}$ & $x$ & $x$ & $\mathrm{x}$ & $x$ & $\sqrt{1}$ & $\sqrt{ }$ \\
\hline 44 & Land Taxation & $\mathrm{x}$ & $x$ & $\sqrt{1}$ & $\sqrt{ }$ & $\mathrm{x}$ & $\sqrt{ }$ & $\sqrt{ }$ & $\sqrt{ }$ & $\sqrt{1}$ & $\mathrm{x}$ & $\mathrm{x}$ & $\mathrm{x}$ & $\sqrt{ }$ \\
\hline 45 & Land, Housing and the City & $\mathrm{x}$ & $\sqrt{ }$ & $x$ & $\mathrm{x}$ & $x$ & $x$ & $x$ & $x$ & $x$ & $x$ & $x$ & $\sqrt{1}$ & $x$ \\
\hline 46 & Law of Contract and Tort & $x$ & $x$ & $\sqrt{ }$ & $\sqrt{1}$ & $\sqrt{ }$ & $x$ & $\sqrt{ }$ & $\sqrt{ }$ & $x$ & $x$ & $\sqrt{ }$ & $\sqrt{1}$ & $\sqrt{ }$ \\
\hline 47 & Law of Real Property/Real Estate Law & $x$ & $\sqrt{ }$ & $\sqrt{1}$ & $\sqrt{ }$ & $x$ & $\sqrt{ }$ & $\sqrt{ }$ & $\sqrt{ }$ & $\sqrt{1}$ & $\sqrt{ }$ & $\sqrt{ }$ & & $x$ \\
\hline 48 & Macroeconomic Theory I \& II & $\mathrm{x}$ & $\mathrm{x}$ & $\sqrt{ }$ & $\mathrm{x}$ & $\mathrm{x}$ & $\mathrm{x}$ & $\mathrm{x}$ & $\mathrm{x}$ & $\mathrm{x}$ & $\mathrm{x}$ & $\mathrm{x}$ & $\mathrm{x}$ & $\mathrm{x}$ \\
\hline
\end{tabular}




\begin{tabular}{|c|c|c|c|c|c|c|c|c|c|c|c|c|c|c|}
\hline 49 & Management and Leadership & $\mathrm{x}$ & $\sqrt{1}$ & $x$ & $\mathrm{x}$ & $\mathrm{x}$ & $\mathrm{x}$ & $\mathrm{x}$ & $\mathrm{x}$ & $x$ & $\mathrm{x}$ & $\mathrm{x}$ & $\mathrm{x}$ & $\mathrm{x}$ \\
\hline 50 & Mathematics for Business and Social Sciences & $\sqrt{1}$ & $\mathrm{x}$ & $\mathrm{x}$ & $\mathrm{x}$ & $\mathrm{x}$ & $\mathrm{x}$ & $\sqrt{1}$ & $\mathrm{x}$ & $\mathrm{x}$ & $\mathrm{x}$ & $\mathrm{x}$ & $\mathrm{x}$ & $\mathrm{x}$ \\
\hline 51 & $\begin{array}{l}\text { Mathematics for Property Studies/Mathematics for Real Estate/Mathematics of } \\
\text { Finance }\end{array}$ & $\mathrm{x}$ & $\sqrt{ }$ & $\sqrt{ }$ & $\sqrt{ }$ & $\mathrm{x}$ & $\mathrm{x}$ & $\sqrt{ }$ & $\sqrt{ }$ & $\sqrt{ }$ & $\mathrm{x}$ & $\mathrm{x}$ & $\sqrt{ }$ & $\mathrm{x}$ \\
\hline 52 & Natural Resource Economics & $\mathrm{x}$ & $\mathrm{x}$ & $\sqrt{ }$ & $\mathrm{x}$ & $\mathrm{x}$ & $\mathrm{x}$ & $\mathrm{x}$ & $\sqrt{ }$ & $\mathrm{x}$ & $\mathrm{x}$ & $\mathrm{x}$ & $\mathrm{x}$ & $\mathrm{x}$ \\
\hline 53 & Organisational Psychology & $\sqrt{ }$ & $x$ & $\mathrm{x}$ & $x$ & $\mathrm{x}$ & $\mathrm{x}$ & $x$ & $x$ & $\mathrm{x}$ & $\mathrm{x}$ & $\mathrm{x}$ & $\mathrm{x}$ & $\mathrm{x}$ \\
\hline 54 & Physical Environment & $\mathrm{x}$ & $x$ & $\sqrt{ }$ & $\sqrt{ }$ & $x$ & $\mathrm{x}$ & $x$ & $x$ & $\mathrm{x}$ & $\mathrm{x}$ & $\mathrm{x}$ & $\mathrm{x}$ & $\mathrm{x}$ \\
\hline 55 & $\begin{array}{l}\text { Principles of Accounting and Financial Management/Principles of Finance and } \\
\text { Accounting }\end{array}$ & $\sqrt{ }$ & $\mathrm{x}$ & $\sqrt{ }$ & $\mathrm{x}$ & $\mathrm{x}$ & $\mathrm{x}$ & $\mathrm{x}$ & $\mathrm{x}$ & $\mathrm{x}$ & $\mathrm{x}$ & $\mathrm{x}$ & $\sqrt{ }$ & $x$ \\
\hline 56 & Principles of Agriculture and Forestry & $\mathrm{x}$ & $x$ & $\sqrt{ }$ & $\mathrm{x}$ & $\mathrm{x}$ & $\mathrm{x}$ & $\mathrm{x}$ & $\mathrm{x}$ & $\mathrm{x}$ & $\mathrm{x}$ & $\mathrm{x}$ & $\mathrm{x}$ & $x$ \\
\hline 57 & Principles of GIS & $\sqrt{ }$ & $\mathrm{x}$ & $\mathrm{x}$ & $\mathrm{x}$ & $\mathrm{x}$ & $\mathrm{x}$ & $\mathrm{x}$ & $\mathrm{x}$ & $\mathrm{x}$ & $\mathrm{x}$ & $\mathrm{x}$ & $\mathrm{x}$ & $\mathrm{x}$ \\
\hline 58 & Principles of Management \& Organisation Design/Principles of Management & $\sqrt{ }$ & $\mathrm{x}$ & $\sqrt{ }$ & $\sqrt{ }$ & $\mathrm{x}$ & $\mathrm{x}$ & $\sqrt{ }$ & $\mathrm{x}$ & $\sqrt{ }$ & $\sqrt{ }$ & $\mathrm{x}$ & $\mathrm{x}$ & $\mathrm{x}$ \\
\hline 59 & $\begin{array}{l}\text { Principles of Valuation/Applied Valuation I, II \& III/Real Estate Valuation/Advanced RE } \\
\text { Valuation/Property Valuation }\end{array}$ & $\sqrt{ }$ & $\sqrt{ }$ & $\sqrt{ }$ & $\sqrt{ }$ & $\sqrt{ }$ & $\sqrt{ }$ & $\sqrt{ }$ & $\sqrt{ }$ & $\sqrt{ }$ & $\sqrt{ }$ & $\sqrt{ }$ & $\sqrt{ }$ & $\sqrt{ }$ \\
\hline 60 & Professional Ethics/Professional Practice and Ethics & $\sqrt{ }$ & $\mathrm{x}$ & $\sqrt{ }$ & $\mathrm{x}$ & $\mathrm{x}$ & $\sqrt{ }$ & $\mathrm{x}$ & $\mathrm{x}$ & $\mathrm{x}$ & $\mathrm{x}$ & $\mathrm{x}$ & $\mathrm{x}$ & $\mathrm{x}$ \\
\hline 61 & Project Management Theory and Practice/Project Planning and Implementation & $\sqrt{ }$ & $\mathrm{x}$ & $\sqrt{ }$ & $\mathrm{x}$ & $\mathrm{x}$ & $\sqrt{ }$ & $\sqrt{ }$ & $\mathrm{x}$ & $\sqrt{ }$ & $\sqrt{ }$ & $\mathrm{x}$ & $\mathrm{x}$ & $\mathrm{x}$ \\
\hline 62 & Property Auctioneering & $\sqrt{ }$ & $\mathrm{x}$ & $\mathrm{x}$ & $\mathrm{x}$ & $\mathrm{x}$ & $x$ & $\mathrm{x}$ & $\mathrm{x}$ & $\mathrm{x}$ & $\mathrm{x}$ & $\mathrm{x}$ & $\mathrm{x}$ & $\mathrm{x}$ \\
\hline 63 & Property Conveyance and Disposition & $\sqrt{ }$ & $\mathrm{x}$ & $\mathrm{x}$ & $\mathrm{x}$ & $\mathrm{x}$ & $\sqrt{ }$ & $\mathrm{x}$ & $\mathrm{x}$ & $\mathrm{x}$ & $\mathrm{x}$ & $\mathrm{x}$ & $\mathrm{x}$ & $\mathrm{x}$ \\
\hline 64 & $\begin{array}{l}\text { Property Development and Finance/Real Estate Development/Property and } \\
\text { Infrastructure Development }\end{array}$ & $\sqrt{ }$ & $\sqrt{ }$ & $\sqrt{ }$ & $\sqrt{ }$ & $\sqrt{ }$ & $\sqrt{ }$ & $\sqrt{ }$ & $\sqrt{ }$ & $\sqrt{ }$ & $\sqrt{ }$ & $\sqrt{ }$ & $\sqrt{ }$ & $\sqrt{ }$ \\
\hline 65 & Property Investment and Appraisal/Investment Appraisal and Analysis & $\sqrt{1}$ & $x$ & $\sqrt{ }$ & $\sqrt{ }$ & $\sqrt{1}$ & $\sqrt{ }$ & $\mathrm{x}$ & $\mathrm{x}$ & $x$ & $\sqrt{1}$ & $\sqrt{ }$ & $\mathrm{x}$ & $\sqrt{ }$ \\
\hline 66 & Property Maintenance/Construction Maintenance & $\sqrt{ }$ & $\mathrm{x}$ & $\sqrt{ }$ & $\mathrm{x}$ & $\mathrm{x}$ & $\mathrm{x}$ & $\sqrt{1}$ & $\mathrm{x}$ & $\sqrt{ }$ & $\sqrt{1}$ & $\mathrm{x}$ & $\mathrm{x}$ & $\sqrt{ }$ \\
\hline 67 & Property Management/Real Estate Management & $\sqrt{ }$ & $\sqrt{ }$ & $\mathrm{x}$ & $\sqrt{ }$ & $\sqrt{ }$ & $\mathrm{x}$ & $\sqrt{ }$ & $\mathrm{x}$ & $\sqrt{ }$ & $\sqrt{ }$ & $\sqrt{ }$ & $\mathrm{x}$ & $\mathrm{x}$ \\
\hline 68 & Public Administration in Botswana & $\sqrt{ }$ & $\mathrm{x}$ & $\mathrm{x}$ & $\mathrm{x}$ & $\mathrm{x}$ & $\mathrm{x}$ & $\mathrm{x}$ & $\mathrm{x}$ & $\mathrm{x}$ & $\mathrm{x}$ & $\mathrm{x}$ & $\mathrm{x}$ & $\mathrm{x}$ \\
\hline 69 & Quantitative Methods/Quantitative Studies & $\sqrt{ }$ & $\mathrm{x}$ & $\mathrm{x}$ & $\sqrt{ }$ & $\sqrt{ }$ & $\mathrm{x}$ & $\mathrm{x}$ & $\mathrm{x}$ & $\mathrm{x}$ & $\mathrm{x}$ & $\mathrm{x}$ & $\mathrm{x}$ & $\mathrm{x}$ \\
\hline 70 & Real Estate Finance/Real Estate Finance and Taxation & $\mathrm{x}$ & $\sqrt{1}$ & $\sqrt{ }$ & $\sqrt{ }$ & $\mathrm{x}$ & $\mathrm{x}$ & $\mathrm{x}$ & $\mathrm{x}$ & $\sqrt{ }$ & $\mathrm{x}$ & $\sqrt{ }$ & $\sqrt{1}$ & $\sqrt{1}$ \\
\hline 71 & $\begin{array}{l}\text { Real Estate Marketing and Agency/Property Marketing and Agency/Real Estate } \\
\text { Markets Analysis }\end{array}$ & $\sqrt{ }$ & $\sqrt{ }$ & $\sqrt{ }$ & $\mathrm{x}$ & $\sqrt{ }$ & $\sqrt{ }$ & $\mathrm{x}$ & $\mathrm{x}$ & $x$ & $\mathrm{x}$ & $\mathrm{x}$ & $\mathrm{x}$ & $\sqrt{ }$ \\
\hline 72 & Real Estate Principles & $\mathrm{x}$ & $\sqrt{ }$ & $\mathrm{x}$ & $\mathrm{x}$ & $\mathrm{x}$ & $\mathrm{x}$ & $\mathrm{x}$ & $\mathrm{x}$ & $x$ & $\mathrm{x}$ & $\mathrm{x}$ & $\mathrm{x}$ & $\mathrm{x}$ \\
\hline 73 & Remote Sensing for Land Management & $\sqrt{ }$ & $x$ & $\mathrm{x}$ & $x$ & $\mathrm{x}$ & $x$ & $\mathrm{x}$ & $x$ & $x$ & $\mathrm{x}$ & $\mathrm{x}$ & $x$ & $x$ \\
\hline 74 & Research Methodology/Research Methods/Academic writing & $\sqrt{ }$ & $\mathrm{x}$ & $\sqrt{ }$ & $\sqrt{ }$ & $\mathrm{x}$ & $\sqrt{ }$ & $\mathrm{x}$ & $\sqrt{ }$ & $\sqrt{1}$ & $\mathrm{x}$ & $\mathrm{x}$ & $\mathrm{x}$ & $\mathrm{x}$ \\
\hline 75 & Research Project/Honours Research Report/Thesis & $\sqrt{ }$ & $\sqrt{1}$ & $\sqrt{1}$ & $\sqrt{ }$ & $\sqrt{ }$ & $\sqrt{ }$ & $\mathrm{x}$ & $\sqrt{ }$ & $\mathrm{x}$ & $\mathrm{x}$ & $\mathrm{x}$ & $\mathrm{x}$ & $\mathrm{x}$ \\
\hline 76 & Science and Technology in Development & $\mathrm{x}$ & $\mathrm{x}$ & $\sqrt{ }$ & $\mathrm{x}$ & $\mathrm{x}$ & $\mathrm{x}$ & $\mathrm{x}$ & $\mathrm{x}$ & $\mathrm{x}$ & $\mathrm{x}$ & $\mathrm{x}$ & $\mathrm{x}$ & $\mathrm{x}$ \\
\hline 77 & Social Environment & $\mathrm{x}$ & $\mathrm{x}$ & $\mathrm{x}$ & $\sqrt{ }$ & $\mathrm{x}$ & $\mathrm{x}$ & $\sqrt{ }$ & $\mathrm{x}$ & $\mathrm{x}$ & $\mathrm{x}$ & $\mathrm{x}$ & $\mathrm{x}$ & $\mathrm{x}$ \\
\hline 78 & Tribal Land Management & $\sqrt{ }$ & $\mathrm{x}$ & $\mathrm{x}$ & $\mathrm{x}$ & $\mathrm{x}$ & $x$ & $\mathrm{x}$ & $x$ & $\mathrm{x}$ & $\mathrm{x}$ & $\mathrm{x}$ & $\mathrm{x}$ & $\mathrm{x}$ \\
\hline
\end{tabular}

Sources: University of Nairobi, Kenya; Department of Real Estate and Construction Management 2009; University of Witwatersrand, School of Construction Economics and Management; South Africa; University of Botswana Undergraduate Academic Calendar 2013/2014; Ba Isago University College Bachelor of Commerce Real Estate Brochure 2013/2014; the Copperbelt University, BSc. Real Estate Studies, Zambia, internet websites and email.

\subsubsection{Differences in real estate curricula offered in Botswana and other countries}

The study shows that $94 \%$ of the courses offered in these universities are different as outlined in figure $8.40 \%$ of the courses are not offered in Botswana. 65\% of the courses are not offered in South Africa; 35\% of the courses are not offered in Kenya as well and 64\% are not offered in Zambia as illustrated in figure 7. In Tanzania $71 \%$ of the courses on the global list were neither offered nor part of the curriculum. 81\% of the courses did not form part of the Real Estate curriculum in South Korea and China. In Japan $77 \%$ of the courses were not in their real estate curriculum. $79 \%$ of the courses were not part of the curriculum in the Baltic States. The differences in the curricula for real estate education were $76 \%$ for Zimbabwe, $71 \%$ for Ghana, $62 \%$ for Nigeria and $68 \%$ for Malawi.

The courses that are not offered in Botswana include: Administrative and Local government/commercial Law; Agricultural Economics and Management; Applied Corporate/Business Finance; Architectural Drawing and Design/Plan for Property Developers/Studio Projects; Building science I; Commercial Real Estate Investments, Contracts and Procurement in Real Estate Services; Corporate Real Estate; Environment Impact Assessments and audits, HIVIAIDS, Housing Administration even though it is offered as a topic in Housing Economics and Policies; Intellectual Property law; introductory Econometrics; Land Information Systems; Land Policy Studies and Development is also offered a major topic in Land Administration; Land Taxation; Land, Housing and The City; Law of Contract and Tort; Law of Real Property; Management and Leadership; Mathematics for Property Studies; Natural Resources Economics; Physical Environment (Geography) Principles of Agriculture and Forestry; Real Estate Finance and Taxation; Real Estate Principles; Science 
and Technology in Development and Social Environment (Sociology) as shown in table 5 with a cross (x).

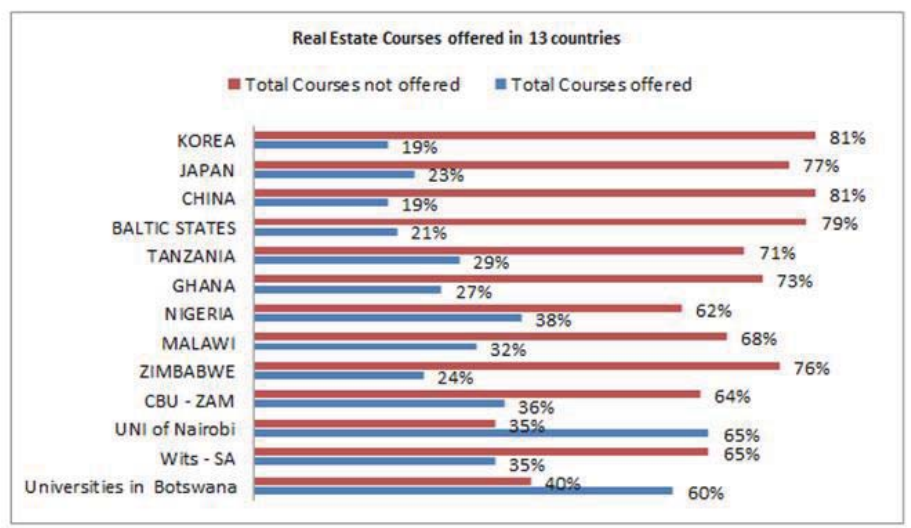

Figure 7: Real Estate courses offered in 13 countries

\subsubsection{Similarities in real estate curricula offered in Botswana and those offered in other countries}

The results in figure 8 revealed that only $6 \%$ of the courses offered in these universities were similar in all respect. Out of these courses $60 \%$ were offered by universities in Botswana; $35 \%$ offered by the University of Witwatersrand in South Africa; $65 \%$ by the University of Nairobi in Kenya and $36 \%$ by the Copperbelt University in Zambia as shown in figure 5. The results show that the courses are comparable internationally to some extent but we are still very far from achieving the level of standardisation of the real estate education curricula in Botswana as well as in other countries.

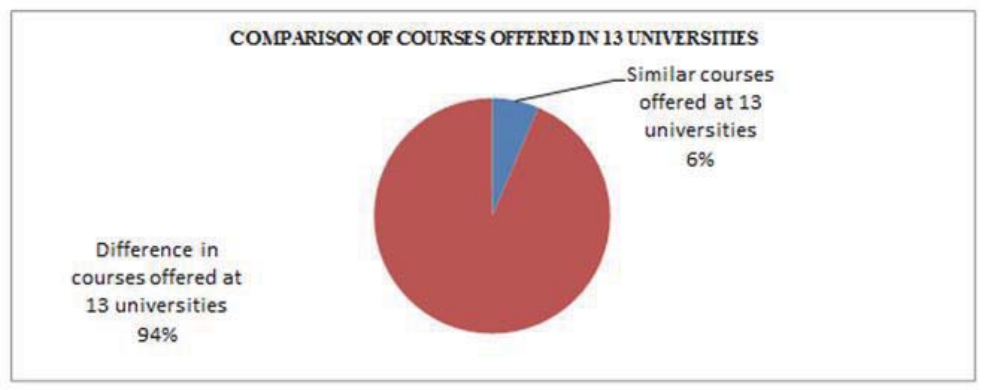

Figure 8: Comparison of course in real estate offered in African universities

\subsection{Analysis}

From the results of the study, it is clear that the differences in the curricula for real estate education are higher than the similarities which is the main reason for failure to standardise the real estate programmes worldwide. This is a major global challenge as noted by Epley (1996). The call for standardisation of real estate curricula in learning institutions by South African Qualifications Authority (SAQA), National Qualifications Framework (NQA) and Epley (1996) is far-fetched globally as well as in Botswana. The results from this study in Botswana are in agreement with what other scholars have found and established in terms of differences and similarities in the curricula for real estate education. The differences are attributed to the diverse nature of the real estate programmes, different land tenure systems as well as the specific various needs of the industry that is being served by these programmes. 


\section{Conclusion}

The paper analysed three undergraduate real estate curricula (certificate, diploma and degree) offered by the two universities in Botswana. At the local level, the difference for certificate real estate curricula is $73 \%, 68 \%$ for diploma programmes and $61 \%$ for degree programmes. This is a clear indicator of the difficulty that institutions face in developing a standardised curricula for real estate education. The results showed similarities in the curricula that are offered in real estate education in Botswana. The variation in the curricula is significant and somehow concludes that educators have not agreed on common topics/courses that should be included in the syllabus. This may be as a result of locational attributes in which the universities are located so that they are able to meet the local industries' property needs and perceptions of the developers of the curricula. The curricula might be tailor-made to suit the needs of the sponsor as was the case with the land management programme at the University of Botswana. Since the Real Estate curricula is multidisciplinary, it is expected that the graduates of these curricula are ready to meet the stakeholders' needs in the property industry both in the public and private sectors of Botswana and elsewhere in the world which is a critical element on the part of the employer. The fact that the graduates of such programmes are mobile, means they might be employed in any labour market in the world thus the need to consider standardising the curricula that are developed for real estate education.

\section{References}

Black, R. T., and Rabianski, J. S. (2003). Defining the real estate body of knowledge: A survey approach. Journal of Real Estate Practice and Education, Vol. 6(No. 1), 33 - 54.

Black, R. T., Carn, N. G., Diaz, J., and Rabianski, J. S. (1996). The Role of the American Real Estate Society in definig and promulgating the study of real property. The Journal of Real Estate Research, Vol. 12(No. 2), 183-193.

Botswana, Republic of. (2007). Real Estate Professionals Act. Gaborone: Government Printers.

Butler, J. Q., Gunterman, K. L., and Wolverton, M. (1998). Integrating the real estate curriculum. Journal of Real Estate Prctice and Education, Vol. 1(No. 1), 51 -66.

Carn, N. G., and Rabianski, J. S. (1986). Real Estate and the AACSB's common body of knowledge. Journal of Real Estate Issues, 42 48.

Cloete, C. E. (2009). Training Valuers in SA: The Future. 4th Mass Appraisal Valuation Sympossium, March 25 - 28. Pretoria, RSA.

Epley, D. R. (1996). The current body of knowledge paradigms used in real estate education and issues in need of further research. The Journal of Real Estate Research, Vol.12(No. 2), 229-236.

Finch, J. H., and Weeks, H. S. (2003). An analysis of Real Estate curriculum at AACSB International - Accredited Institutions. Journal of Real Estate Practice and Education, Vol. 6(No. 2), 257 - 268.

Galuppo, L. A., and Worzala, E. (2004). A study into important elements of a Masters Degree in Real Estate. Journal of Real Estate Practice and Education, 7(1), 25-45.

Nourse, H. F. (1995). A Note on the Origin of Real Estate in Collegiate Schools of Business Administration. Journal of Real Estate Research, Vol. 10(No. 2), 227-234.

Olima, W. H. (2006). Re - Engineering Real Estate Education and Training in Kenya. Africa Region CASLE Conference on sustainable land management in Africa, March 14 - 17. Bagamoyo, Tanzania.

Olima, W. H. (2009). Training of Valuers in Kenya. 4th Mass Appraisal Valuation Sympossium, March 25 - 28. Pretoria, RSA. 